\title{
ERRATUM
}

Mohammad Mohammadianpanah •

Shapour Omidvari · Ahmad Mosalaei •

Niloofar Ahmadloo

\section{Treatment results of tonsillar lymphoma: a 10-year experience}

Published online: 1 May 2004

C) Springer-Verlag 2004

\section{Annals Hematol (2004) s00277-004-0860-0}

Two authors' surnames were given incorrectly. The correct spellings are given here:

Shapour Omidvari, Ahmad Mosalaei

The online version of the original article can be found at http://dx. doi.org/10.1007/s00277-004-0860-0

M. Mohammadianpanah $(\bowtie) \cdot$ S. Omidvari · A. Mosalaei ·

N. Ahmadloo

Department of Radiation Oncology, Shiraz University of

Medical Sciences,

Shiraz, Fars, Iran (Islamic Republic)

e-mail: mohpanah@sums.ac.ir 